Jurnal ELTIKOM, Vol. 1 No.1, Juni 2017, Hal 9-17 ISSN 2598-3245 (Print), ISSN 2598-3288 (Online)

Tersedia Online di http://eltikom.poliban.ac.id

\title{
OPTIMASI ON-LOAD TAP-CHANGING MENGGUNAKAN QUANTUM DIFFERENTIAL EVOLUTION UNTUK MEMINIMALKAN KERUGIAN DAYA
}

\author{
Aji Akbar Firdaus \\ Universitas Airlangga \\ e-mail: aji.akbar.firdaus11@gmail.com
}

\begin{abstract}
One of the functions of a transformator is a device that can regulate the voltage on a system. Settings this voltage can be done in several ways, one way to adjust the voltage using tap transformator. In this paper, transformator tap arrangement is done by Quantum Differential Evolution (QDE) method. This transformator tap setting aims to improve the voltage and minimize power loss. This scheme is tested on IEEE 34-bus $20 \mathrm{kV}$ system. From the simulation results, before tap power is used, the obtained loss transformator is $21.76 \mathrm{~kW}$ with $19 \mathrm{kV}$ average voltage and after setting the transformator tap is applied, the power loss become $19.16 \mathrm{~kW}$ with $19.93 \mathrm{kV}$ average voltage.
\end{abstract}

Keywords: tap transformator, quantum differential evolution, losses.

ABSTRAK

Salah satu fungsi dari transformator merupakan alat yang dapat mengatur tegangan pada sebuah sistem. Pengaturan Tegangan ini dapat dilakukan dengan beberapa cara, salah satu cara untuk mengatur tegangan tersebut menggunakan tap transformator. Dalam artikel ini, pengaturan tap transformator dilakukan dengan metode Quantum Differential Evolution (QDE). Pengaturan tap transformator ini bertujuan untuk memperbaiki tegangan dan meminimalkan kerugian daya. Skema ini diujikan pada sistem IEEE 34-bus $20 \mathrm{kV}$. Dari hasil simulasi diperoleh bahwa sebelum dilakukan tap transformator kerugian daya didapatkan $21.76 \mathrm{~kW}$ dengan tegangan rata-rata $19 \mathrm{kV}$ dan setelah pengaturan tap transformator dilakukan kerugian daya menjadi $19.16 \mathrm{~kW}$ dengan tegangan rata-rata $19.93 \mathrm{kV}$.

Kata Kunci: tap transformator, quantum differential evolution, kerugian daya.

\section{PENDAHULUAN}

$\mathrm{P}$ ertambahan penduduk yang ada sekarang menyebabkan semakin meningkatnya kebutuhan listrik. Kenaikan kebutuhan listrik ini menyebabkan timbulnya masalah-masalah teknis, seperti kerugian daya. Ada beberapa cara untuk mengatasi kerugian daya yang diakibatkan pertambahan beban dan perluasaan jaringan, misalnya dengan rekonfigurasi untuk mengurangi kerugian tegangan dan memperbaiki tegangan yang kurang baik [1], dengan pengurangan tegangan untuk mengurangi permintaan listrik dengan mempertahankan tegangan yang dikirimkan ke pelanggan [2], menggunakan energi terbarukan dengan PV untuk mengendalikan tegangan [3], perbaikan tegangan dan pengurangan kerugian daya dengan kompensator statis [4], maupun dengan cara koordinasi on load tap changer (OLTC) sehingga trafo dapat mengontrol tegangan [5].

Untuk mengkoordinasikan OLTC ini diperlukan suatu metode control. Koordinasi OLTC juga dapat dilakukan dengan distributed generator dan PV [6]. Namun hal ini membutuhkan waktu yang lama, disebabkan koordinasi dilakukan dengan manual sedangkan penambahan DG dan PV dapat juga menambah biaya operasi dan perubahan beban yang terjadi setiap waktu.

Kebutuhan energi listrik dalam skala besar diperlukan untuk memenuhi kebutuhan energi yang meningkat. Dengan pertambahan beban ini memunculkan adanya penambahan saluran dimana jarak antar beban dan pembangkit listrik semakin jauh. Ada 2 jenis saluran yang dimaksud disini, yaitu saluran transmisi dan saluran distribusi [7]. Gambar 1 merupakan gambar dari sistem penyaluran daya listrik dari pembangkit sampai beban. Dalam sistem penyaluran tenaga listrik, Ada beberapa bagian yaitu pembangkit, saluran transmisi, dan saluran distribusi. 
Pada jaringan distribusi, ada beberapa permasalahan yang dapat mengganggu kehandalan dan kontinyuitas dari penyaluran tenaga listrik. Permasalahan itu antara lain kerugian daya dan tegangan jatuh [8]. Parameter-parameter yang mempengaruhi persoalan tersebut adalah resistansi, induktansi, dan konduktansi dari saluran dan beban.

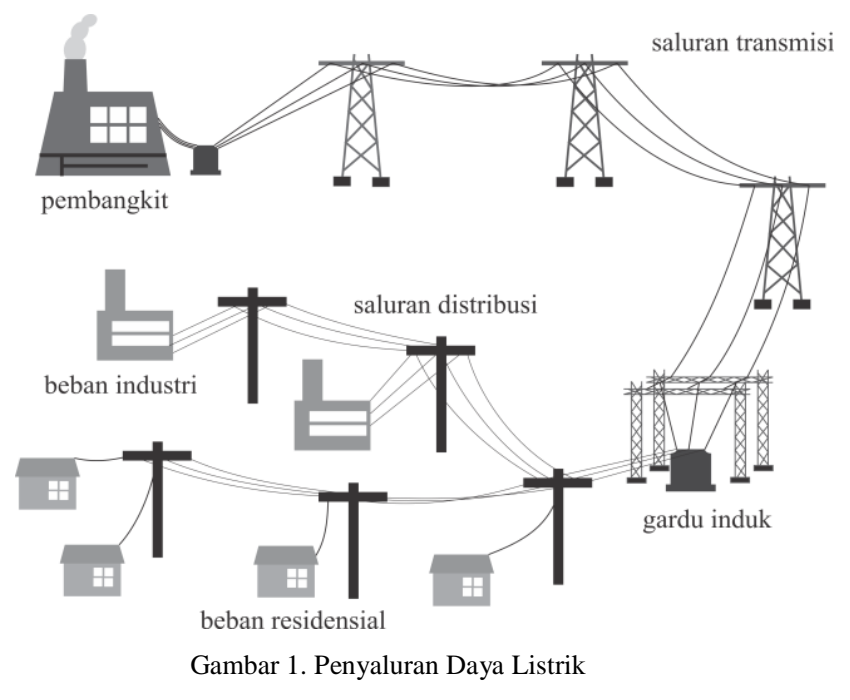

Dalam artikel ini, QDE digunakan untuk mengkoordinasikan OLTC sehingga kerugian daya dari sistem bisa dibuat menjadi lebih rendah. Dalam penelitian ini, skema yang dipakai telah diujikan pada sistem IEEE 34-bus 20kV. Dengan optimasi koordinasi OLTC ini diharapkan agar tegangan dapat diperbaiki dan kerugian daya bisa diminimalisir.

\section{Metode PENELITIAN}

Dalam penelitian ini digunakan sebuah model hipotetis berupa jaringan distribusi radial yang terdiri dari 6 bus dan 5 beban (Gambar 2). Dalam tahapan penelitian ini, dilakukan 2 proses: (a) menghitung aliran daya pada jaringan distribusi menggunakan bus injection to branch current (BIBC) dan branch current to bus voltage (BCBV) dan selanjutnya (b) menggunakan Quantum Differential Evolution (QDE) untuk memperoleh anggota populasi. Masing-masing tahapan ini dapat dijelaskan berikut ini.

\section{A. Aliran Daya pada Jaringan Distribusi Radial}

Bus Injection to Branch Current (BIBC) merupakan pembentukan matriks impedansi dengan melakukan penelusuran alur saluran distribusi [9]. Gambar 2 merupakan contoh jaringan distribusi radial yang terdiri dari 6 bus dan 5 beban.

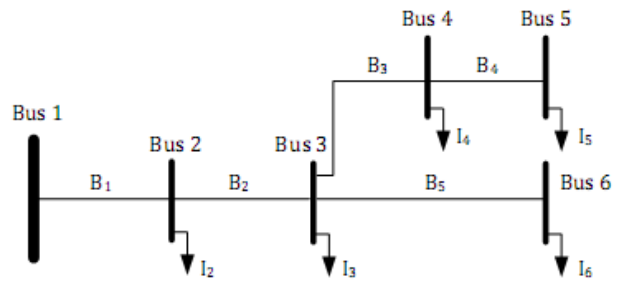

Gambar 2 Jaringan Distribusi Radial

Injeksi arus pada tiap cabang dilakukan menggunakan persamaan (1).

$\mathrm{B}_{5}=\mathrm{I}_{6}$

$\mathrm{B}_{4}=\mathrm{I}_{5}$

$\mathrm{B}_{3}=\mathrm{I}_{4}+\mathrm{I}_{5}$

$\mathrm{B}_{2}=\mathrm{I}_{3}+\mathrm{I}_{4}+\mathrm{I}_{5}+\mathrm{I}_{6}$

$\mathrm{B}_{1}=\mathrm{I}_{2}+\mathrm{I}_{3}+\mathrm{I}_{4}+\mathrm{I}_{5}+\mathrm{I}_{6}$ 


$$
\begin{aligned}
& {\left[\begin{array}{l}
B 1 \\
B 2 \\
B 3 \\
B 4 \\
B 5
\end{array}\right]=\left[\begin{array}{ccccc}
-1 & -1 & -1 & -1 & -1 \\
0 & -1 & -1 & -1 & -1 \\
0 & 0 & -1 & -1 & 0 \\
0 & 0 & 0 & -1 & 0 \\
0 & 0 & 0 & 0 & -1
\end{array}\right]\left[\begin{array}{l}
I 2 \\
I 3 \\
I 4 \\
I 5 \\
I 6
\end{array}\right]} \\
& {[\mathrm{BIBC}]=-\mathrm{K}=-\left[\begin{array}{ccccc}
-1 & -1 & -1 & -1 & -1 \\
0 & -1 & -1 & -1 & -1 \\
0 & 0 & -1 & -1 & 0 \\
0 & 0 & 0 & -1 & 0 \\
0 & 0 & 0 & 0 & -1
\end{array}\right]=\left[\begin{array}{lllll}
1 & 1 & 1 & 1 & 1 \\
0 & 1 & 1 & 1 & 1 \\
0 & 0 & 1 & 1 & 0 \\
0 & 0 & 0 & 1 & 0 \\
0 & 0 & 0 & 0 & 1
\end{array}\right]}
\end{aligned}
$$

Branch Current to Bus Voltage (BCBV) menyatakan hubungan antara arus cabang dan tegangan bus. Persamaan (3) merupakan persamaan hubungan antara arus cabang dan tegangan.

$\mathrm{V}_{1}-\mathrm{V}_{2}=\mathrm{B}_{1} \mathrm{Z}_{12}$

$\mathrm{V}_{1}-\mathrm{V}_{3}=\mathrm{B}_{1} \mathrm{Z}_{12}+\mathrm{B}_{2} \mathrm{Z}_{23}$

$V_{1}-V_{4}=B_{1} Z_{12}+B_{2} Z_{23}+B_{3} Z_{34}$

$V_{1}-V_{5}=B_{1} Z_{12}+B_{2} Z_{23}+B_{3} Z_{34}+B_{4} Z_{45}$

$\mathrm{V}_{1}-\mathrm{V}_{6}=\mathrm{B}_{1} \mathrm{Z}_{12}+\mathrm{B}_{2} \mathrm{Z}_{23}+\mathrm{B}_{5} \mathrm{Z}_{56}$

$$
\left[\begin{array}{l}
V 1 \\
V 1 \\
V 1 \\
V 1 \\
V 1
\end{array}\right]-\left[\begin{array}{l}
V 2 \\
V 3 \\
V 4 \\
V 5 \\
V 6
\end{array}\right]=\left[\begin{array}{ccccc}
Z 12 & 0 & 0 & 0 & 0 \\
Z 12 & Z 23 & 0 & 0 & 0 \\
Z 12 & Z 23 & Z 34 & 0 & 0 \\
Z 12 & Z 23 & Z 34 & Z 45 & 0 \\
Z 12 & Z 23 & 0 & 0 & Z 56
\end{array}\right]\left[\begin{array}{l}
B 1 \\
B 2 \\
B 3 \\
B 4 \\
B 5
\end{array}\right]
$$

Persamaan (4) merupakan persamaan untuk menghitung tegangan jatuh.

$$
\begin{aligned}
& {[\Delta \mathrm{V}]=[\mathrm{BCBV}][\mathrm{B}]} \\
& {[\Delta \mathrm{V}]=[\mathrm{BCBV}][\mathrm{BIBC}][\mathrm{I}]} \\
& {[\Delta \mathrm{V}]=[\mathrm{DLF}][\mathrm{I}]}
\end{aligned}
$$

Penyelesaian aliran daya dapat diperoleh dengan prosedur perhitungan secara iterasi dengan persamaan (5) dan (7).

$$
\begin{aligned}
\mathrm{I}_{\mathrm{i}}^{(\mathrm{k})} & =\left(\frac{P i+j Q i}{V i(k)}\right)^{*} \\
{\left[\Delta \mathrm{V}^{\mathrm{k}}\right] } & =[\mathrm{DLF}]\left[\mathrm{I}^{\mathrm{k}}\right] \\
{\left[\mathrm{V}^{\mathrm{k}+1}\right] } & =\left[\mathrm{V}_{1}\right]-\left[\Delta \mathrm{V}^{\mathrm{k}}\right]
\end{aligned}
$$

Berikutnya menghitung aliran daya aktif dan reaktif seperti persamaan (8) dan (9).

$$
\begin{aligned}
\mathrm{P}_{\mathrm{ij}} & =\operatorname{real}\left[\mathrm{V}_{\mathrm{i}}\left\{\left(\mathrm{V}_{\mathrm{i}}-\mathrm{V}_{\mathrm{j}}\right) \mathrm{y}_{\mathrm{ij}}\right\}^{*}\right] \\
\mathrm{Q}_{\mathrm{ij}} & =\operatorname{imag}\left[\mathrm{V}_{\mathrm{i}}\left\{\left(\mathrm{V}_{\mathrm{i}}-\mathrm{V}_{\mathrm{j}}\right) \mathrm{y}_{\mathrm{ij}}\right\}^{*}\right]
\end{aligned}
$$

Dan selanjutnya rugi-rugi daya dapat dihitung seperti persamaan (10).

$$
\text { Ploss }=\sum_{k=1}^{N b} \mathrm{Zk}\left(\frac{\mathrm{Pk}^{2}+\mathrm{Qk}^{2}}{\mathrm{Vk}^{2}}\right)
$$


B. Quantum Differential Evolution (QDE)

Differential Evolution (QDE) merupakan metode metaheuristic yang diperkenalkan Storn dan Price pada tahun 1997 [10]. DE dikembangkan dari Algoritma Genetic Annealing dimana algoritma Genetic Annealing ini merupakan metode metaheuristic yang didasarkan pada pembangkitan populasi dengan melakukan perturbasi (perturbation) pada suatu faktor mutan untuk membentuk populasi mutan. Populasi mutan dengan populasi target dikombinasikan dengan operator crossover untuk membangkitkan populasi percobaan. Kemudian, nilai fungsi fitness dibandingkan melalui operator seleksi antara populasi percobaan dengan populasi target. Individu terbaik yang dihasilkan dari hasil perbandingan hasil crossover dan fitness ini nantinya akan dijadikan sebagai anggota populasi selanjutnya. Proses ini diulang sampai mendapatkan nilai individu yang optimal.

Langkah-langkah algoritma DE diberikan sebagai berikut:

1. Inisialiasi populasi

2. Melakukan crossover

3. Melakukan mutasi

4. Melakukan selection

5. Local search

6. Selanjutnya prosedur ini diulang kembali ke langkah 2 sedemikian rupa sampai iterasi maksimum.

Quantum Differential Evolution ( $Q D E)$ merupakan pengembangan dari algoritma DE. Salah satu parameter pembeda yang digunakan dalam QDE adalah contraction-expansion coefficient. Parameter ini digunakan untuk mengatur crossover, mutase, dan selection konvergensi dari variasi differential [11].

\section{HASIL DAN PEMBAHASAN}

Dalam penelitian ini jaringan radial sistem IEEE 34-bus $20 \mathrm{kV}$ digunakan sebagai model. Letak OLTC pada sistem IEEE 34 bus ada pada line antara bus 3 dan 4, bus 9 dan 13, bus 15 dan 16, bus 21 dan 25, bus 30 dan 31 sebagamana diberikan pada Gambar 3. Data-data jaringan dan beban pada setiap bus diambil dari [12] yang dilampirkan pada Tabel I dan Tabel II. Total daya aktif dari beban ini adalah $428.64 \mathrm{~kW}$, sedangkan kerugian daya yang diperoleh dari sistem distribusi sebesar $21.76 \mathrm{~kW}$ dengan tegangan rata-rata $19.00 \mathrm{kV}$ dimana tegangan terendah adalah $18.56 \mathrm{kV}$. Nilai tersebut didapatkan dengan formasi tap untuk trafo 1 sampai trafo 5 secara berurutan yaitu $-1,0,2,-1,0$.

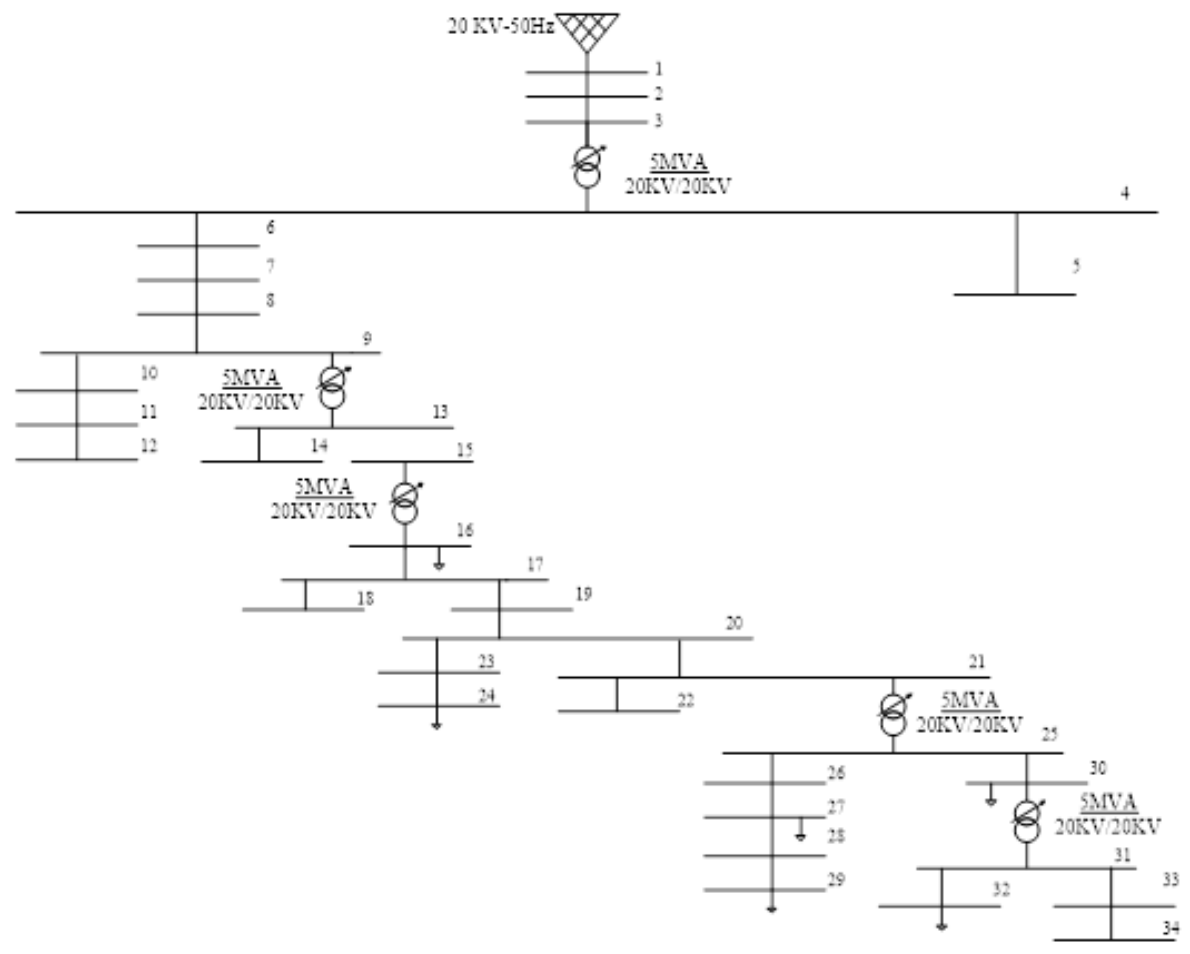

Gambar 3. Sistem IEEE 34-Bus 


\begin{tabular}{|c|c|c|c|c|}
\hline \multicolumn{5}{|c|}{$\begin{array}{c}\text { TABEL I. } \\
\text { DATA SALURAN }\end{array}$} \\
\hline \multicolumn{5}{|c|}{ Data Saluran } \\
\hline \multicolumn{2}{|c|}{ cabang } & \multicolumn{2}{|c|}{ Impedansi } & Trafo \\
\hline bus & bus & $\mathrm{R}$ & $X$ & \\
\hline 1 & 2 & 0.6532 & 0.6518 & 0 \\
\hline 2 & 3 & 0.438 & 0.4371 & 0 \\
\hline 3 & 4 & 8.1601 & 8.143 & 0 \\
\hline 4 & 5 & 1.4695 & 1.4664 & 0 \\
\hline 4 & 6 & 9.4943 & 9.4744 & 0 \\
\hline 6 & 7 & 7.5271 & 7.5113 & 0 \\
\hline 7 & 8 & 0.0037 & 0.0027 & 0 \\
\hline 8 & 9 & 0.1133 & 0.0829 & 0 \\
\hline 9 & 10 & 0.9067 & 0.4811 & 0 \\
\hline 10 & 11 & 25.524 & 13.544 & 0 \\
\hline 11 & 12 & 7.2851 & 3.8657 & 0 \\
\hline 9 & 13 & 3.7321 & 2.7294 & 0 \\
\hline 13 & 14 & 0.307 & 0.2246 & 0 \\
\hline 13 & 15 & 1.6062 & 0.8525 & 0 \\
\hline 15 & 16 & 7.4714 & 5.5642 & 0 \\
\hline 16 & 17 & 0.1901 & 0.139 & 0 \\
\hline 17 & 18 & 12.368 & 6.5638 & 0 \\
\hline 17 & 19 & 13.462 & 9.8548 & 0 \\
\hline 19 & 20 & 0.0037 & 0.0027 & 0 \\
\hline 20 & 21 & 1.7911 & 1.3099 & 0 \\
\hline 21 & 22 & 0.8588 & 0.4558 & 0 \\
\hline 20 & 23 & 0.053 & 0.026 & 0 \\
\hline 23 & 24 & 2.6736 & 2.668 & 0 \\
\hline 21 & 25 & 2.131 & 1.5585 & 0 \\
\hline 25 & 26 & 0.1023 & 0.0749 & 0 \\
\hline 26 & 27 & 0.4935 & 0.3609 & 0 \\
\hline 27 & 28 & 1.3305 & 0.9731 & 0 \\
\hline 28 & 29 & 0.1937 & 0.1417 & 0 \\
\hline 25 & 30 & 0.7384 & 0.54 & 0 \\
\hline 30 & 31 & 0.9796 & 0.7164 & 0 \\
\hline 31 & 32 & 0.3144 & 0.2299 & 0 \\
\hline 31 & 33 & 0.1023 & 0.0749 & 0 \\
\hline 33 & 34 & 1.7688 & 1.3082 & 0 \\
\hline
\end{tabular}

\begin{tabular}{|c|c|c|c|}
\hline \multicolumn{4}{|c|}{$\begin{array}{l}\text { TABEL II. } \\
\text { DATA BUS }\end{array}$} \\
\hline \multicolumn{4}{|c|}{ Bus Data } \\
\hline bus & $\mathrm{P}(\mathrm{MW})$ & Q(MVAR) & Tipe Beban \\
\hline 2 & 0 & 0 & 0 \\
\hline 3 & 0 & 0 & 0 \\
\hline 4 & 0 & 0 & 0 \\
\hline 5 & 0 & 0 & 0 \\
\hline 6 & 0 & 0 & 0 \\
\hline 7 & 0 & 0 & 0 \\
\hline 8 & 0 & 0 & 0 \\
\hline 9 & 0 & 0 & 0 \\
\hline 10 & 0 & 0 & 0 \\
\hline 11 & 0 & 0 & 0 \\
\hline 12 & 0 & 0 & 0 \\
\hline 13 & 0 & 0 & 0 \\
\hline 14 & 0 & 0 & 0 \\
\hline 15 & 0 & 0 & 0 \\
\hline 16 & 0.01 & 0.005 & 3 \\
\hline 17 & 0 & 0 & 0 \\
\hline 18 & 0 & 0 & 0 \\
\hline 19 & 0 & 0 & 0 \\
\hline 20 & 0 & 0 & 0 \\
\hline 21 & 0 & 0 & 0 \\
\hline 22 & 0 & 0 & 0 \\
\hline 23 & 0 & 0 & 0 \\
\hline 24 & 0.15 & 0.075 & 2 \\
\hline 25 & 0 & 0 & 0 \\
\hline 26 & 0 & 0 & 0 \\
\hline 27 & 0.135 & 0.105 & 3 \\
\hline 28 & 0 & 0 & 0 \\
\hline 29 & 0.02 & 0.016 & 1 \\
\hline 30 & 0.02 & 0.016 & 1 \\
\hline 31 & 0 & 0 & 0 \\
\hline 32 & 0.009 & 0.007 & 2 \\
\hline 33 & 0 & 0 & 0 \\
\hline 34 & 0 & 0 & 0 \\
\hline
\end{tabular}

Dari hasil simulasi aliran daya awal menggunakan formasi tap untuk trafo 1 sampai trafo 5 secara berurutan adalah -1, 0, 2, -1, 0 terlihat seperti Tabel III. Pada Gambar 4, diberikan tegangan bus sistem yang berada di bawah batasan toleransi yang ditentukan yaitu $\pm 5 \%$ dari tegangan base yaitu $20 \mathrm{kV}$ dan tegangan paling rendah terjadi pada bus 16 sampai dengan 34. Kerugian daya pada saluran trafo 1 sampai trafo 5 masing-masingnya adalah $3.29 \mathrm{~kW}, 1.5 \mathrm{~kW}, 3.01 \mathrm{~kW}, 0.27 \mathrm{~kW}$ dan $0 \mathrm{~kW}$. Kerugian daya ini diakibatkan karena arus yang mengalir pada trafo sangat besar. 
TABEL III.

\begin{tabular}{|c|c|c|c|c|c|c|}
\hline \multirow{2}{*}{$\begin{array}{l}\text { dari } \\
\text { bus }\end{array}$} & \multirow{2}{*}{$\begin{array}{l}\text { ke } \\
\text { bus }\end{array}$} & \multicolumn{2}{|c|}{ arus } & \multicolumn{2}{|c|}{ kerugian daya } & \multirow{2}{*}{$\begin{array}{c}\text { tegangan } \\
\text { jatuh } \\
\mathrm{kV}\end{array}$} \\
\hline & & A & deg & $\mathrm{kW}$ & kVAR & \\
\hline 1 & 2 & 20.07 & -33.29 & 0.26 & 0.26 & 0.02 \\
\hline 2 & 3 & 20.07 & -33.29 & 0.18 & 0.18 & 0.01 \\
\hline 3 & 4 & 20.07 & -33.29 & 3.29 & 3.28 & 0.23 \\
\hline 4 & 5 & 0 & 0 & 0 & 0 & 0 \\
\hline 4 & 6 & 20.07 & -33.29 & 3.82 & 3.82 & 0.26 \\
\hline 6 & 7 & 20.07 & -33.29 & 3.03 & 3.03 & 0.21 \\
\hline 7 & 8 & 20.07 & -33.29 & 0 & 0 & 0 \\
\hline 8 & 9 & 20.07 & -33.29 & 0.05 & 0.03 & 0 \\
\hline 9 & 10 & 0 & 0 & 0 & 0 & 0 \\
\hline 10 & 11 & 0 & 0 & 0 & 0 & 0 \\
\hline 11 & 12 & 0 & 0 & 0 & 0 & 0 \\
\hline 9 & 13 & 20.07 & -33.29 & 1.5 & 1.1 & 0.09 \\
\hline 13 & 14 & 0 & 0 & 0 & 0 & 0 \\
\hline 13 & 15 & 20.07 & -33.29 & 0.65 & 0.34 & 0.04 \\
\hline 15 & 16 & 20.07 & -33.29 & 3.01 & 2.24 & 0.19 \\
\hline 16 & 17 & 19.55 & -33.46 & 0.07 & 0.05 & 0 \\
\hline 17 & 18 & 0 & 0 & 0 & 0 & 0 \\
\hline 17 & 19 & 19.55 & -33.46 & 5.14 & 3.76 & 0.33 \\
\hline 19 & 20 & 19.55 & -33.46 & 0 & 0 & 0 \\
\hline 20 & 21 & 11.27 & -38.58 & 0.23 & 0.17 & 0.02 \\
\hline 21 & 22 & 0 & 0 & 0 & 0 & 0 \\
\hline 20 & 23 & 8.39 & -26.57 & 0 & 0 & 0 \\
\hline 23 & 24 & 8.39 & -26.57 & 0.19 & 0.19 & 0.03 \\
\hline 21 & 25 & 11.27 & -38.58 & 0.27 & 0.2 & 0.03 \\
\hline 25 & 26 & 9.32 & -38.54 & 0.01 & 0.01 & 0 \\
\hline 26 & 27 & 9.32 & -38.54 & 0.04 & 0.03 & 0.01 \\
\hline 27 & 28 & 1.38 & -39.2 & 0 & 0 & 0 \\
\hline 28 & 29 & 1.38 & -39.2 & 0 & 0 & 0 \\
\hline 25 & 30 & 1.95 & -38.82 & 0 & 0 & 0 \\
\hline 30 & 31 & 0.57 & -37.87 & 0 & 0 & 0 \\
\hline 31 & 32 & 0.57 & -37.87 & 0 & 0 & 0 \\
\hline 31 & 33 & 0 & 0 & 0 & 0 & 0 \\
\hline 33 & 34 & 0 & 0 & 0 & 0 & 0 \\
\hline
\end{tabular}

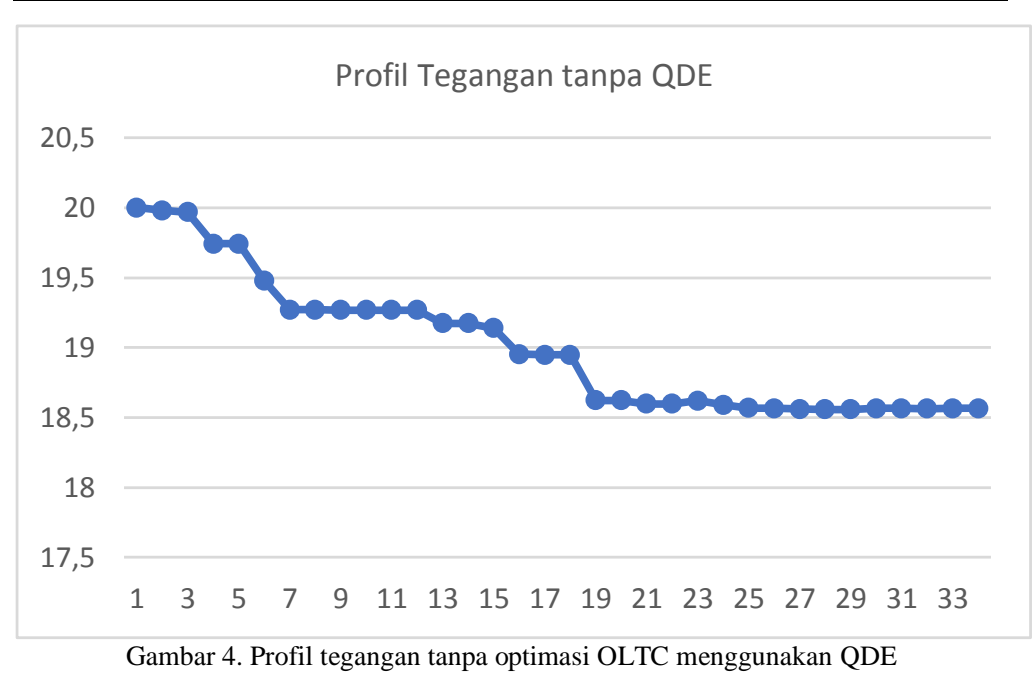

Simulasi optimasi menggunakan QDE pada system, koordinasi tap trafo 1 sampai 5 adalah 2, 1, 3, 3, 3. Dengan rincian dari hasil simulasi sebaagimana diberikan pada Tabel IV. Arus pada line yang terdapat trafo menurun ditunjukkan pada Tabel V. Hal ini dikarenakan tap trafo yang dilakukan dapat mengubah aliran daya, sehingga hal tersebut dapat meminimalkan kerugian daya dan memperbaiki tegangan. Kerugian daya yang dihasilkan dalam skema ini sebesar $19.16 \mathrm{~kW}$ dengan tegangan rata-rata sebesar $20.56 \mathrm{kV}$. Tidak ada bus yang melebihi $\pm 5 \%$, dengan tegangan terendah berada pada bus 29 dan tegangan tertinggi pada bus 18 seperti Gambar 5. 
TABEL IV.

\begin{tabular}{lrrr}
\multicolumn{4}{c}{ HASIL OPTIMASI OLTC MENGGUNAKAN QDE } \\
\hline & \multicolumn{2}{c}{ Lokasi Saluran } & Tap Trafo \\
& Bus Awal & Bus Akhir & \\
\hline OLTC1 & 3 & 4 & 2 \\
OLTC2 & 9 & 13 & 1 \\
OLTC3 & 15 & 16 & 3 \\
OLTC4 & 21 & 25 & -3 \\
OLTC5 & 30 & 31 & 3 \\
\hline
\end{tabular}

TABEL V.

HASIL ALIRAN DAYA DENGAN OPTIMASI OLTC MENGGUNAKAN QDE

\begin{tabular}{|c|c|c|c|c|c|c|}
\hline \multirow{2}{*}{$\begin{array}{l}\text { dari } \\
\text { bus }\end{array}$} & \multirow{2}{*}{$\begin{array}{l}\text { ke } \\
\text { bus }\end{array}$} & \multicolumn{2}{|c|}{ arus } & \multicolumn{2}{|c|}{ kerugian daya } & \multirow{2}{*}{$\begin{array}{l}\text { tegangan } \\
\text { jatuh } \\
\mathrm{kV}\end{array}$} \\
\hline & & A & deg & $\mathrm{kW}$ & kVAR & \\
\hline 1 & 2 & 19.47 & -33.53 & 0.25 & 0.25 & 0.02 \\
\hline 2 & 3 & 19.47 & -33.53 & 0.17 & 0.17 & 0.01 \\
\hline 3 & 4 & 19.47 & -33.53 & 3.09 & 3.09 & 0.22 \\
\hline 4 & 5 & 0.00 & 0.00 & 0.00 & 0.00 & 0.00 \\
\hline 4 & 6 & 19.47 & -33.53 & 3.60 & 3.59 & 0.26 \\
\hline 6 & 7 & 19.47 & -33.53 & 2.85 & 2.85 & 0.20 \\
\hline 7 & 8 & 19.47 & -33.53 & 0.00 & 0.00 & 0.00 \\
\hline 8 & 9 & 19.47 & -33.53 & 0.04 & 0.03 & 0.00 \\
\hline 9 & 10 & 0.00 & 0.00 & 0.00 & 0.00 & 0.00 \\
\hline 10 & 11 & 0.00 & 0.00 & 0.00 & 0.00 & 0.00 \\
\hline 11 & 12 & 0.00 & 0.00 & 0.00 & 0.00 & 0.00 \\
\hline 9 & 13 & 19.47 & -33.53 & 1.14 & 0.77 & 0.09 \\
\hline 13 & 14 & 0.00 & 0.00 & 0.00 & 0.00 & 0.00 \\
\hline 13 & 15 & 19.47 & -33.53 & 0.61 & 0.32 & 0.04 \\
\hline 15 & 16 & 19.47 & -33.53 & 2.36 & 1.55 & 0.18 \\
\hline 16 & 17 & 18.89 & -33.73 & 0.07 & 0.05 & 0.00 \\
\hline 17 & 18 & 0.00 & 0.00 & 0.00 & 0.00 & 0.00 \\
\hline 17 & 19 & 18.89 & -33.73 & 4.80 & 3.52 & 0.31 \\
\hline 19 & 20 & 18.89 & -33.73 & 0.00 & 0.00 & 0.00 \\
\hline 20 & 21 & 11.37 & -38.53 & 0.23 & 0.17 & 0.03 \\
\hline 21 & 22 & 0.00 & 0.00 & 0.00 & 0.00 & 0.00 \\
\hline 20 & 23 & 7.62 & -26.57 & 0.00 & 0.00 & 0.00 \\
\hline 23 & 24 & 7.62 & -26.57 & 0.16 & 0.16 & 0.03 \\
\hline 21 & 25 & 11.37 & -38.53 & -0.26 & -0.03 & 0.03 \\
\hline 25 & 26 & 9.51 & -38.48 & 0.01 & 0.01 & 0.00 \\
\hline 26 & 27 & 9.51 & -38.48 & 0.04 & 0.03 & 0.01 \\
\hline 27 & 28 & 1.34 & -39.15 & 0.00 & 0.00 & 0.00 \\
\hline 28 & 29 & 1.34 & -39.15 & 0.00 & 0.00 & 0.00 \\
\hline 25 & 30 & 1.86 & -38.80 & 0.00 & 0.00 & 0.00 \\
\hline 30 & 31 & 0.52 & -37.87 & -0.02 & -0.02 & 0.00 \\
\hline 31 & 32 & 0.52 & -37.87 & 0.00 & 0.00 & 0.00 \\
\hline 31 & 33 & 0.00 & 0.00 & 0.00 & 0.00 & 0.00 \\
\hline 33 & 34 & 0.00 & 0.00 & 0.00 & 0.00 & 0.00 \\
\hline
\end{tabular}




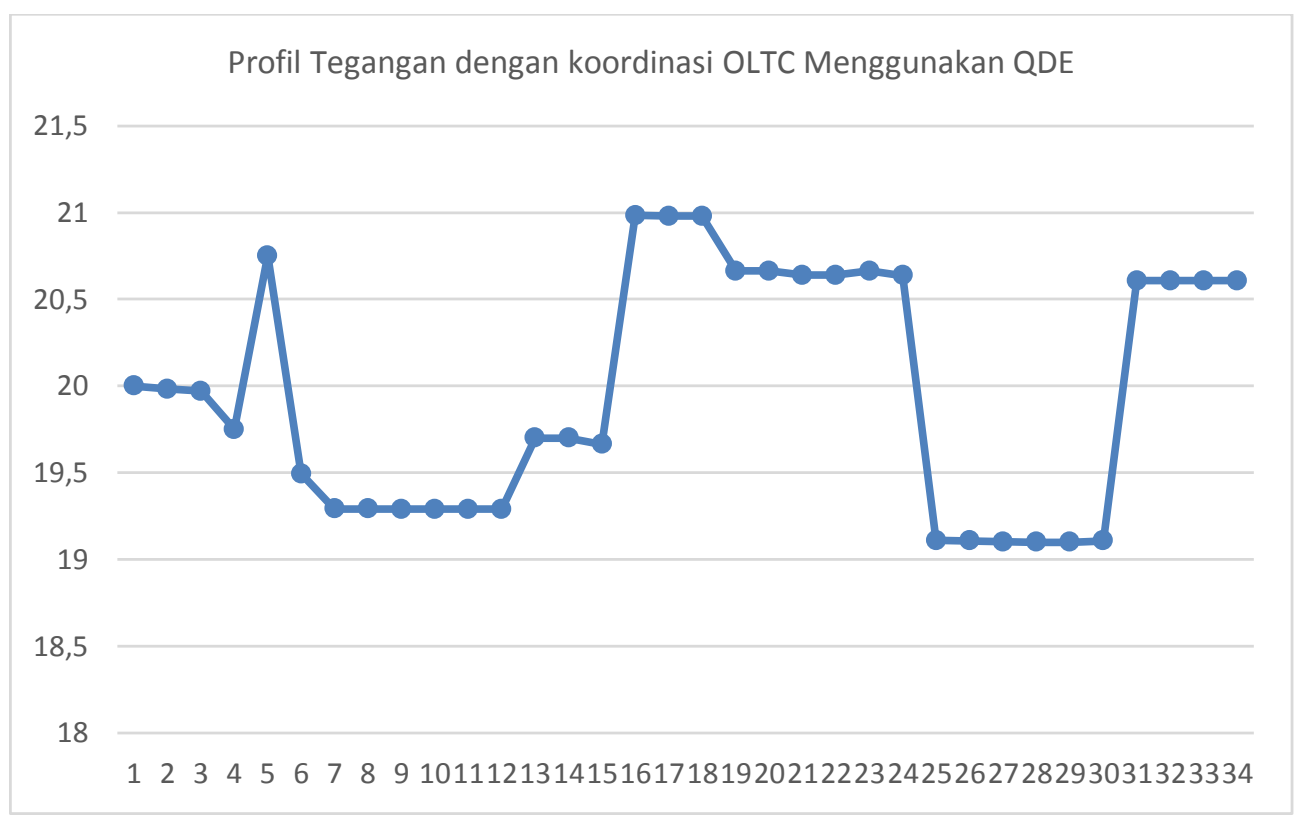

Gambar 5. Profil tegangan dengan optimasi OLTC menggunakan QDE

Pada Tabel VI ditunjukkan perbandingan antara hasil simulasi menggunakan metode GA dan QDE. Berdasarkan Tabel VI, QDE menemukan kerugian daya yang lebih minimal dibandingkan dengan metode GA.

TABEL VI. PERBANDINGAN HASIL SimUlasi PROGRAM

\begin{tabular}{lll}
\hline & GA & QDE \\
\hline $\begin{array}{l}\text { Kerugian Daya } \\
(\mathbf{k W})\end{array}$ & 19.3016 & 19.1573 \\
\hline
\end{tabular}

\section{KESIMPULAN}

Dalam suatu sistem jaringan distribusi terdapat permasalahan yang umum dihadapi yaitu masalah kerugian daya dan tegangan jatuh. Salah satu cara untuk mengatasi kerugian daya dan tegangan jatuh ini adalah dengan menggunakan OLTC. OLTC ini diujikan pada sistem IEEE 34 bus dan optimasi koordinasi OLTC menggunakan QDE. Sebelum dilakukan optimasi koordinasi OLTC, nilai OLTC dari trafo 1 sampai trafo 5 secara berurutan adalah -1, 0, 2, -1, 0 dimana kerugian daya yang diperoleh sebesar $21.76 \mathrm{~kW}$ sedangkan tegangan rata-ratanya adalah $19 \mathrm{kV}$ dengan tegangan paling rendah $18.56 \mathrm{kV}$. Selanjutnya, dari hasil simulasi optimasi OLTC menggunakan QDE didapatkan kerugian daya menjadi sebesar $19.16 \mathrm{~kW}$ sedangkan untuk rata-rata tegangan yang dihasilkan adalah $20.56 \mathrm{kV}$ dimana nilai OLTC dari trafo 1 sampai trafo 5 secara berurutan adalah 2, 1, 3, -3, dan 3 .

\section{DAFTAR PUSTAKA}

[1] M. Sedighizadeh, M. Dakhem, M. Sarvi, H.H. Kordkheili, “Optimal Reconfiguration and Capacitor Placement for Power Loss Reduction of Distribution System Using Improved Binary Particle Swarm Optimization," International Journal of Energy and Environmental Engineering, vol. 5, no. 1, hal. 1-11, 2014.

[2] S. Rahimi, M. Marinelli, F. Silvestro, "Evaluation of requirements for volt/var control and optimization function in distribution management systems," IEEE Int. Energy Conf. Exhibition Energycon, Florence, Italy, 2012, hal. 331-336.

[3] I. Leisse, O. Samuelsson, J. Svensson, "Coordinated voltage control in medium and low voltage distribution networks with wind power and photovoltaics," IEEE PowerTech Conf., Grenoble, France, 2013, hal. 1-6.

[4] C. Kumar, M.K. Mishra, “A voltage-controlled DSTATCOM for power-quality improvement,” IEEE Trans. Power Deliv., vol. 29, no. 3, hal. 1499-1507, 2014.

[5] A. Einfalt, F. Kupzog, H. Brunner, A. Lugmaier, "Control strategies for smart low voltage grids - the project DG DemoNet - smart LV grid," Integration of Renewables into the Distribution Grid, CIRED 2012 Workshop, Lisbon, Portugal, 2012, hal. 1-4.

[6] M.S. El Moursi, H.H. Zeineldin, J.L. Kirtley, "A dynamic master/slave reactive power-management scheme for smart grids with distributed generation,” IEEE Trans. Power Deliv., vol. 29, no. 3, hal. 1157-1167, 2014.

[7] P. Xiao, D.C. Yu, W. Yan, “A Unified Three-Phase Transformer Model for Distribution Load Flow Calculations”, IEEE Transactions On Power Systems, vol. 21, no. 1, hal. 153-159, 2006. 
[8] J.H. Teng, et. al. "A Network Topology based Three Phase Load Flow for Distribution System", Proc.Nat.Sci.Counc.ROC. part A: physical science and engineering, vol. 24, no.4, hal. 259-264, 2000.

[9] T.H. Chen, N.C. Yang, "Three-Phase Power-Flow by Direct Zbr Method for Unbalanced Radial Distribution Systems," IET Gener.Transm.Distrib., vol. 3, no.10, hal. 903-910, 2009.

[10] X.S. Yang, Nature Inspired. Edisi kedua, Luniver Press, 2010.

[11] L. dos Santos Coelho, "A quantum particle swarm optimizer with chaotic mutation operator," Chaos, Solitions and Fractals, vol. 37, no. 5, hal. 1409-1418, 2008.

[12] U. Eminoglu, M.H. Hocaoglu, "A Voltage Stability Index For Radial Distribution Networks", 42th Int. Universities Power Engineering Conf., hal. 408-413, 2007. 